\title{
ARISTOLOCHIC ACIDS IN THE ROOTS OF ARISTOLOCHIA CHILENSIS, A DANGEROUS CHILEAN MEDICINAL PLANT
}

\author{
ALEJANDRO URZÚA*I, ANGEL OLGUÍN, ROCÍO SANTANDER \\ ${ }^{1}$ Laboratory of Chemical Ecology, Department of Environmental Sciences, Faculty of Chemistry and Biology, University of Santiago de Chile, \\ Av. Libertador Bernardo O'Higgins 3363, Santiago, Chile \\ (Received: July 30, 2013 - Accepted: November 21, 2013)
}

\begin{abstract}
The chemical composition of aristolochic acids (AAs) from the roots of A. chilensis was determined by high-performance liquid chromatography with diodearray detection (HPLC-DAD), a technique widely used for the detection and quantification of AAs in herbal medicines. The roots contained a mixture of AA-I (1), AA-II (2), AA-III (3), AA-IV (4), AA-Ia (5), AA-IIIa (6), AA-IVa (7), and aristoloside (8), indicating that $A$. chilensis is not suitable for use as a medicinal plant due to the harmful effects of the aristolochic acids.
\end{abstract}

\section{INTRODUCTION}

Species of the genus Aristolochia (Aristolochiaceae) have been used in folk medicine throughout the world to treat various diseases ${ }^{1}$. Aristolochia can be characterized by their levels of aristolochic acids (AAs), a group of 10-nitrophenanthrene-1-carboxylic acids that normally include a 3,4-methylenedioxy moiety and substitutions at C-6 and/or C-8 with $-\mathrm{OCH}_{3}$ and-OH groups; AAs with the former substitution are known as phenolic AAs. Structures with other types of substituents have also been identified, including $\mathrm{N}$-glycosides and O-glycosides of phenolic AAs. ${ }^{2-4}$

AA-I (1) and AA-II (2) are powerful carcinogens in mice, rats and humans. Studies have shown that these AAs are genotoxic, mutagenic, and nephrotoxic. ${ }^{5-10}$

The mechanism underlying the toxicity of AAs AA-I (1) and AA-II (2) involves a reduction of the nitro group (which is catalyzed by an enzyme) to the very reactive cyclic nitrenium ion, which then binds covalently to DNA and/or proteins. DNA adducts with the reduction products of AAs have been found in the kidney and ureter tissues of rats and humans that had consumed AAs. ${ }^{5,6,10,11}$

In a recent review of the ethnopharmacological properties of this group, 99 species of Aristolochia were included ${ }^{1}$, but the authors obtained phytochemical data for only 24 of these species; for the other species, the part of the plant that was studied was not related to the part used in ethnomedicine. The authors of the review indicated the importance of obtaining new ethnopharmacological, phytochemical, and epidemiological data for Aristolochia used in folk medicine, particularly in Continents where such information is scarce.

The roots of Aristolochia chilensis Bridges ex Lindl. were used in Central Chile during the XIX and XX centuries as an anti-hemorrhagic agent and to expel the residual placenta after childbirth. ${ }^{12}$ The plant was consumed in two ways: as an infusion of approximately $2 \mathrm{~g}$ of powdered roots in a cup of water and as a decoction by boiling 30-40 $\mathrm{g}$ in $250 \mathrm{ml}$ of water. ${ }^{13}$

Although the risk of using $A$. chilensis in folk medicine is evident, the plant continues to be utilized and even promoted on the Internet (http://www. losmedicamentos.net/planta/oreja-de-zorro-hierba-de-la-virgen-maria-clon). This promotion may occur, at least in part, because the content and composition of AAs from the roots of $A$. chilensis have not been studied.

In this study, high-performance liquid chromatography with diodearray detection (HPLC-DAD), a technique widely used for the detection and quantification of AAs in herbal medicine ${ }^{14-24}$ was used to determine the chemical composition of AAs from the roots of A. chilensis. The findings reveal that the roots contain a significant amount of AAs, making it dangerous to use A. chilensis as a medicinal plant because of the harmful effects of AAs.

\section{MATERIALS AND METHODS}

\section{Plant material}

Representative samples of the roots of $A$ chilensis Bridges ex Lindl. were collected during the flowering season at Cuesta Lo Prado $(15 \mathrm{~km}$ west of Santiago, $33^{\circ} 28^{\prime} \mathrm{S}, 70^{\circ} 56^{\prime} \mathrm{W}, 750 \mathrm{~m}$ above sea level) in September 2012. Voucher specimens (SGO-152461) were deposited in the Herbarium of the National Natural History Museum in Santiago, Chile.

\section{Extraction of AAs}

Oven-dried and powdered roots of $A$. chilensis $(40 \mathrm{~g})$ were extracted with light petroleum ether $\left(35-65^{\circ}\right)$ in a Soxhlet apparatus, and the defatted plant material was then extracted with $\mathrm{MeOH}$. The methanolic extract was evaporated in vacuo. The syrupy residue was agitated with $100 \mathrm{~mL}$ of $3 \%$ $\mathrm{NaHCO}_{3}$ for $6 \mathrm{~h}$, allowed to stand for $24 \mathrm{~h}$ at $10{ }^{\circ} \mathrm{C}$, and filtered. The clear filtrate was washed with $\mathrm{CHCl}_{3}(5 \times 50 \mathrm{~mL})$. Upon evaporation, the washings with $\mathrm{CHCl}_{3}$ yielded a brown gum that contained no acids and was not further investigated. The aqueous phase was adjusted to $\mathrm{pH} 2$ with $\mathrm{HCl}$ and extracted with $\mathrm{CHCl}_{3}(6 \times 50 \mathrm{~mL})$. Evaporation of the combined extracts in vacuo yielded a fraction of crude non-phenolic AAs $(43.4 \mathrm{mg})^{22}$. The acid solution was then extracted with AcOEt $(6 \times 50 \mathrm{~mL})$. Evaporation of the combined extracts in vacuo yielded a second fraction of crude phenolic AAs $(103 \mathrm{mg})$. The fraction of crude phenolic AAs was re-suspended in $10 \mathrm{~mL}$ of $3 \% \mathrm{NaHCO}_{3}$ and filtered. The clear filtrate was adjusted to $\mathrm{pH} 2$ with $\mathrm{HCl}$ and extracted with AcOEt $(6$ x $10 \mathrm{~mL}$ ). Evaporation of the combined extracts in vacuo yielded a purified fraction of phenolic AAs $(45.5 \mathrm{mg})^{22}$. This procedure was repeated using five samples ( $40 \mathrm{~g}$ ) of A.chilensis roots obtained from five different plants ${ }^{22}$.

The fractions of both the non-phenolic and phenolic AAs were subjected to preparative TLC on pre-coated plates of silica gel 60 F254 Merck $(1.0 \mathrm{~mm}$ thickness, $20 \times 20 \mathrm{~cm}$ ) in $\mathrm{CHCl}_{3}-\mathrm{MeOH}$ (95:5). Mixtures of AAs were detected under UV irradiation at $365 \mathrm{~nm}$ and eluted from the plates with $\mathrm{CHCl}_{3}-\mathrm{MeOH}$ (70:30). The fractions obtained from each band were then analyzed by HPLCDAD.

\section{HPLC-DAD analysis of AAs}

The AA fractions in $\mathrm{MeOH}$ were directly injected $(20 \mu 1)$ into an analytical HPLC (Waters 600) with a reverse-phase Symmetry column $(5 \mu \mathrm{m}$ particle size; $25 \times 0.46 \mathrm{~cm}$ ). Gradient elution was performed using a mobile phase of $0.1 \%$ acetic acid in water (solution $\mathrm{A}$ ) and $0.1 \%$ acetic acid in acetonitrile (solution B) in the following manner: 0-5 min, isocratic elution with $70 \% \mathrm{~A}$ / $30 \% \mathrm{~B} ; 5-45$ min, linear gradient from $70 \% \mathrm{~A} / 30 \% \mathrm{~B}$ to $55 \% \mathrm{~A} / 45 \% \mathrm{~B}$. A Waters 2996 diode-array-detector (DAD) was used for detection, and spectra were recorded at wavelengths between 200 and $800 \mathrm{~nm}^{22,24}$. The AA fractions from the five collected samples ( $40 \mathrm{~g}$ each), each of which was obtained from a different plant, were analyzed independently.

\section{Acid hydrolysis of compound 8.}

Compound $8(4 \mathrm{mg})$ was dissolved in $2 \mathrm{~mL}$ of $\mathrm{MeOH}$ and $2 \mathrm{~mL}$ of $10 \%$ $\mathrm{HCl}$. The mixture was stirred at room temperature for $5 \mathrm{hr}$; the solvent was then evaporated, and $\mathrm{MeOH}$ was added and evaporated several times until the $\mathrm{HCl}$ was eliminated. The remaining residue was diluted with $\mathrm{H}_{2} \mathrm{O}(2 \mathrm{~mL})$ and extracted with AcOEt; the AcOEt extract yielded AA-IVa (7). The $\mathrm{H}_{2} \mathrm{O}$ layer was evaporated to dryness, yielding a solid $(1.0 \mathrm{mg})$. Final purification was performed via preparative PC using the system $n$-BuOH-EtOH- $\mathrm{H}_{2} \mathrm{O}$ (4:9:1), yielding pure $\mathrm{D}-(+)$-glucose. 
<smiles>[R3]c1cc([R1])c2cc([N+](=O)[O-])c3c(C(=O)O)cc4c(c3c2c1)OCO4</smiles>

$$
\begin{aligned}
& 1 \mathrm{R}_{1}=\mathrm{OCH}_{3} ; \mathrm{R}_{2}=\mathrm{H} \\
& 2 \mathrm{R}_{1}=\mathrm{R}_{2}=\mathrm{H} \\
& 3 \mathrm{R}_{1}=\mathrm{H} ; \mathrm{R}_{2}=\mathrm{OCH}_{3} \\
& 4 \mathrm{R}_{1}=\mathrm{R}_{2}=\mathrm{OCH}_{3} \\
& 5 \mathrm{R}_{1}=\mathrm{OH} ; \mathrm{R}_{2}=\mathrm{H} \\
& 6 \mathrm{R}_{1}=\mathrm{H} ; \mathrm{R}_{2}=\mathrm{OH} \\
& 7 \mathrm{R}_{1}=\mathrm{OCH}_{3} ; \mathrm{R}_{2}=\mathrm{OH} \\
& 8 \mathrm{R}_{1}=\mathrm{OCH}_{3} ; \mathrm{R}_{2}=\mathrm{OG}
\end{aligned}
$$

Nuclear magnetic resonance spectroscopy

Spectra were recorded on a Bruker 400 Ultra Shield spectrometer in DMSO-d $_{6}$.

\section{RESULTS AND DISCUSION}

The AAs (1-7) were identified by HPLC-DAD, a technique widely used to detect and quantify AAs in herbal medicine. ${ }^{14-24}$ Their UV spectra (Figure $\mathrm{N}^{\circ}$ 1) and retention times were compared, and co-injection was performed using standards of AA-I (1), AA-II (2), AA-III (3), AA-IV (4), AA-Ia (5), AA-IIIa

(1)
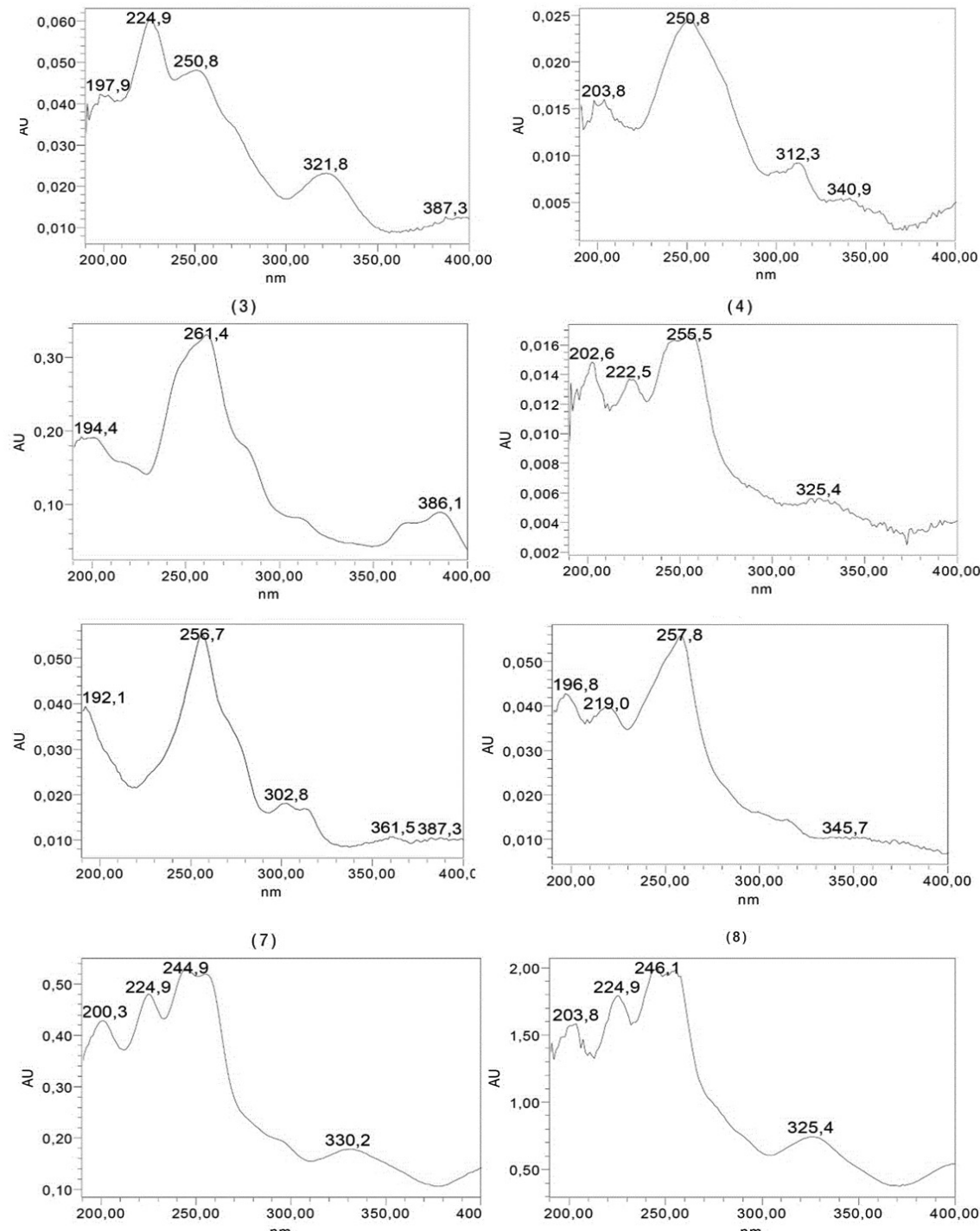

(6), and AA-IVa (7), which had been previously isolated from A. chilensis, A. argentina, and Battus polydamas archidamas ${ }^{22,25,26}$. Quantification was based on peak areas of chromatograms taken at $254 \mathrm{~nm}$. A dilution series of standard solutions was prepared from stock solutions of the standards and all solutions of standards and samples were stored at $5{ }^{\circ} \mathrm{C}$. Calibration lines were obtained by plotting the peak areas against the concentrations of the standards; these lines were used to determine the concentrations of the AAs in the samples. A compound with $\mathrm{RT}=2.5 \mathrm{~min}$ (compound 8) exhibited the same UV spectra as AA-IV (4) $(\mathrm{RT}=32.9 \mathrm{~min})$ and AA-IVa (7) $(\mathrm{RT}=11.8 \mathrm{~min})$, indicating the structure of a 3,4-methylenedioxy-6,8-dioxy-AA. Acid hydrolysis of compound 8 yielded AA-IVa (7) and D-(+)-glucose. The $1 \mathrm{H}$ NMR spectrum showed the expected signals for D-(+)-glucose bound to AA-IVa (7) by glycosylation as the $\beta$-glucopyranoside (anomeric signal at $\delta 4.47$ (d) $\mathrm{J}=6.0$ $\mathrm{Hz}$ ). The spectrum was similar to that of the 6-0- $\beta$-D-glucopyranoside of AAIVa (8) (aristoloside), which was first identified from the stems of Aristolochia manshuriensi ${ }^{27}$ and, in low yield, from Aristolochia argentina roots. ${ }^{25}$

The AAs identified in A. chilensis roots, expressed as $\mathrm{mg} / \mathrm{kg}$ of dry material are shown in Table 1. Although the same set of compounds, with the exception of compound (8), were identified in the leaves and stems, ${ }^{22}$ their concentrations in the roots are very different. Phenolic components and the 6-0- $\beta$-D-glucopyranoside of aristolochic acid-IVa (8) accounted for nearly $72.5 \%$ of the total mixture, whereas they represented only $27 \%$ of the total in the leaves and stems. In the roots, AA-IVa (7) and the 6-0- $\beta$-D-glucopyranoside of aristolochic acid-IVa (8) formed the principal components by a large margin.
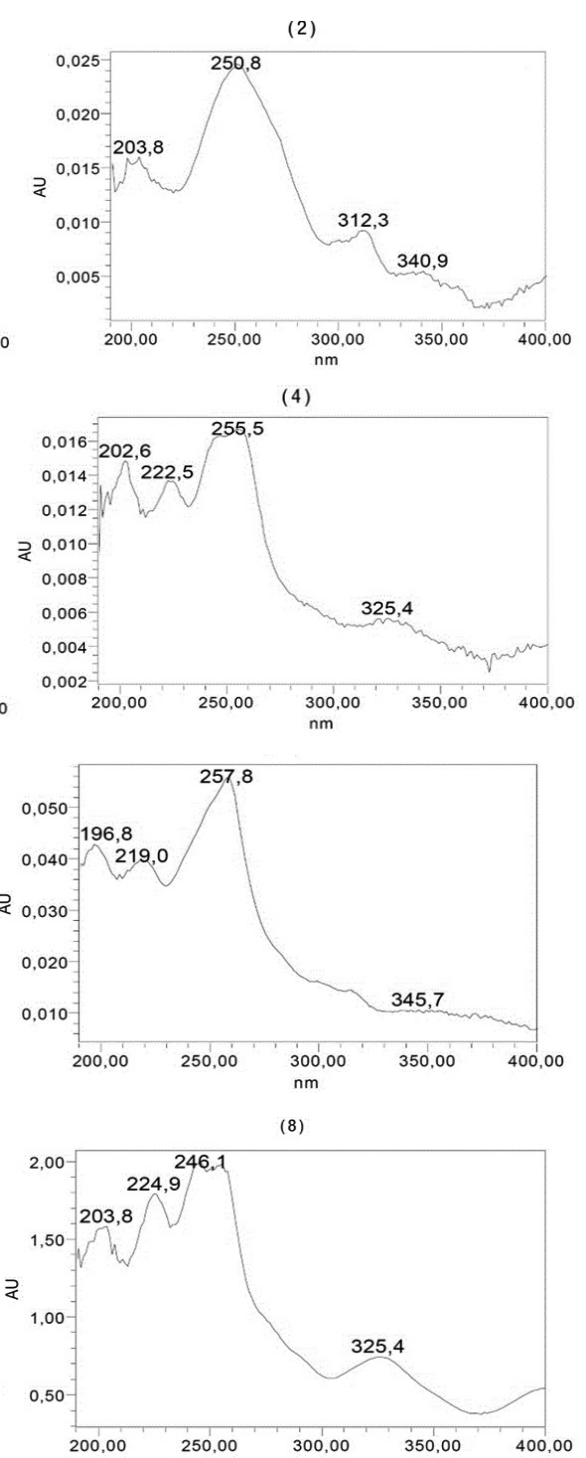

Figure 1. UV spectra of Aristolochic acids (1-8) obtained by HPLC-DAD analysis. 
Table 1. Aristolochic acids from the roots of Aristolochia chilensis

\begin{tabular}{|c|c|c|c|}
\hline AAs & $\mathbf{m g} / \mathbf{k g}$ in the roots $^{\mathbf{a}}$ & $\mathbf{R T}(\mathbf{m i n})$ & $\mathbf{U V} \boldsymbol{\lambda}_{\text {max }}$ (nm), Figure 1 \\
\hline IVa-OG(8) & $600(67)$ & 2.5 & $203.8,224.9,246.1,255.0,325.4,400.0$ \\
\hline IIIa (6) & $57(6)$ & 8.4 & $196.8,219.0,257.8,315.0$ \\
\hline IVa (7) & $599(71)$ & 11.8 & $200.3,224.5,244.9,255.1,320.2,400.0$ \\
\hline Ia (5) & $\operatorname{tr}$ & 12.92 & $256.7,270$ sh, 302.8, 323.2 \\
\hline III (3) & $196(21)$ & 22.9 & $194.4,261.4,276.0$ sh, 299sh, 368.2, 386.1 \\
\hline II (2) & $22(3)$ & 26.3 & $203.8,250.8,312.3,340.9$ \\
\hline I (1) & $32(4)$ & 30.7 & $197.9,224.9,250.8,321.8$ \\
\hline IV (4) & $\operatorname{tr}$ & 32.9 & $202.6,222.5,245.1,255.5,325.4,400.0$ \\
\hline
\end{tabular}

${ }^{a}$ Mean of five independent analyses (SD in parentheses). Abbreviations: RT, retention time; tr, trace amounts.

Because AA-I (1) and AA-II(2) can be easily obtained commercially and are much more widely distributed in Aristolochia, ${ }^{2}$ studies of the toxicity and mechanisms of action of AAs have been mostly restricted to those compounds. ${ }^{5-10}$ An exception is a study of the toxicity of several AA derivatives in cultured rat renal epithelial cells, ${ }^{7}$ in which AA-I (1), AA-II (2), AA-VIIIa, and AA-Ia (5) were shown to have nearly identical levels of activity, while other AA derivatives, AA-III (3), AA-IIIa (6), AA-IVa (7), AA-VIa, and 7-hydroxyAA-I, were nearly inactive. These results indicate a direct relationship between the activity and localization of the substituents in the structure of the AAs. However, differences in the uptake, distribution, and metabolism of the AA derivatives may influence the in vivo toxicity of these compounds.

In another study, rats treated orally over the course of three months with a dose of $1.0 \mathrm{mg} / \mathrm{kg}$ of a mixture of AA-I (1) and AA-II (2) developed cancer, mainly in the stomach, kidney, and urinary tract ${ }^{28}$.

\section{CONCLUSIONS}

In the Chilean countryside, women suffering from certain menstrual problems use $A$. chilensis as a medicinal plant. This practice involves monthly intake during menstruation of decoctions of 30-40 $\mathrm{g}$ of A. chilensis roots, each dose containing an estimated 45 to $60 \mathrm{mg}$ of AAs. There have been no epidemiological studies in Chile that have examined a potential increase in cancer pathologies in areas with higher consumption of A. chilensis; regardless, its use as a medicinal plant is a potential health risk. Therefore, the plant should be removed from the market as a precaution, and its use should be banned due to the toxic effects of AAs.

\section{ACKNOWLEDGEMENTS}

This work was supported by FONDECYT Chile Grant N ${ }^{\circ} 1120037$

\section{REFERENCES}

1. M. Heinrich, J. Chan, S. Wanke, C. Neinhuis, MSJ. Simmonds, J. Ethnopharm. 125, 108, (2009).

2. V. Kumar, AK. Prasad, VS. Parmar, Nat. Prod. Rep. 20, 565, (2003).

3. KW. Bentley, Nat. Prod. Rep. 23, 444, (2006).

4. P-C. Kuo, Y-C. Li, T-S. Wu, J. Trad. Comp. Med. 2, 249, (2011).

5. VM. Arlt, M. Stiborova, HH. Schmeiser, Mutagenesis 17, 265, (2002).
6. S. Zhou, H-L. Koh, Y. Gao, Z-Y. Gong, EJD. Lee, Life Sci. 74, 935, (2004).

7. P. Balachandran, F. Wei, RC. Lin, IA. Khan, DS. Pasco, Kidney Int. 67, 1797, (2005).

8. N. Mei , VM. Artl, DH. Phillips, RH. Heflich, T. Chen, Mutat. Res. 602, 83, (2006).

9. S. Shibutani, H. Dong, N. Suzuki, S. Ueda, F. Miller, AP. Grollman, Drug Metab. Dispos. 35, 1217, (2007).

10. Y. Hao, CH. Wan, Y. Kong-Jie, G. Lin, L. Ning, L. Hu-Wei, C. Zong-Wei Science in China series B: Chemistry 52, 1576, (2009).

11. HA. Priestap, C de los Santos, JME. Quirke, J. Nat. Prod. 73, 1979, (2010).

12. P. Riedemann, G. Aldunate, Flora Nativa de Valor Ornamental, Chile Centro, Editorial Andrés Bello: Santiago Chile, 2001; pp. 344-345.

13. J. Zin, C. Weiss, La salud por Medio de Plantas Medicinales. Ed. Salesiana, Santiago, Chile, 1998.

14. K. Hashimoto, M. Higuchi, B. Makino, I. Sakakibara, M. Kubo, Y. Komatsu, M. Maruno, M. Okada, J. Ethnopharm. 64, 185, (1999).

15. J-H. Jou, C-Y. Li, EP. Schelonka, C-H. Lin, T-S. Wu, J. Food Drug Anal. 12, 40, (2004).

16. BT. Schaneberg, IA. Khan, J. Ethnopharm. 94, 245, (2004).

17. FQ. Alali, K. Tawaha, MB. Shehadeh, S. Telfah, Z Naturforsch C 61, 685 (2006).

18. W. Chan, KM. Hui, WT. Poon, KC. Lee, Z. Cai, Anal. Chim. Acta 576, $112,(2006)$

19. C. Zhang, X. Wang, M. Shang, J. Yu, Y. Xu, Z. Li, L. Lei, X. Li, S. Cai, T. Namba, Biomed. Chromatogr. 20, 305, (2006).

20. J. Yuan, L. Nie, D. Zeng, X. Luo, F. Tang, L. Ding, Q. Liu, M. Guo, S. Yao, Talanta 73, 644, (2007).

21. J. Yuan, Q. Liu, W. Zhub, L. Ding, F. Tang, S. Yao, J. Chromatogr A 1182 , $85,(2008)$.

22. A. Urzúa, R. Santander, G. Sotes, J. Chil. Chem. Soc. 54, 437, (2009).

23. J. Heaton, L. Whiley, Y. Hong, CM. Sebastian, NW. Smith, C. LegidoQuigley, J. Sep. Sci. 34, 1111, (2011).

24. CF. Pinto, A. Urzúa, HM. Niemeyer, Eur. J. Entomol. 108, 41, (2011).

25. HA. Priestap, Phytochemistry 26, 519 (1987).

26. A. Urzúa, R. Rodríguez, B. Cassels, Biochem. Syst. Ecol. 15, 687, (1987).

27. T. Nakanishi, K. Iwasaki, M. Nasu, I. Miura K. Yoneda, Phytochemistry 21, 1759, (1982).

28. National Toxicology Program, Department of Health and Human Services. Report on Carcinogens, Twelfth Edition, 45, (2011) 